\title{
Power of Judicial Review: A Yardstick to keep the Tribunals within their Boundaries
}

\author{
Subhash Chandra Gupta and Meenakshi* \\ Department of law, H.N.B. Garhwal University (A Central University), B.G.R Campus Pauri Garhwal \\ Uttarakhand-India. 246001 \\ *Corresponding Author Email: meenakshinautiyalkukreti1992@gmail.com
}

Received: 1.12.2021; Revised: 28.12.2021; Accepted: 29.12.2021

(O) Society for Himalayan Action Research and Development

\begin{abstract}
Judicial Review is a power of the judiciary, which protects our constitutional norms and legal framework. Judicial Review ensures the legal fraternity of society. The power of Judicial review deals with the theory of check and balance. The judiciary has been using the power for maintaining law and order in society. At present tribunals are playing a supplemental role in the justice delivery system, the judicial review is important for regulating the tribunals. The research article focuses on the power of judicial review over the working of tribunals. The paper analyses how the judiciary fixes the limitations over the working of tribunals and all quasi-judicial bodies and also focuses on the fact that judicial review is not anti of Tribunalisation it is protector of the tribunal system and judiciary playing an important role of development in tribunalisation.
\end{abstract}

Keywords- Constitutionality, Judicial Review, Jurisdiction, Tribunalisation.

\section{Introduction}

"Judicial quest in administrative matters has been to find the right balance between the administrative discretion to decide matters whether contractual or political in nature or issues of social policy; thus, they are not essentially justifiable but need to remedy any unfairness. Such an unfairness is set right by judicial review." 1

The system of Tribunalisation is not very old for administrative law, the system of tribunals developed with the scheme of welfare state. Tribunalisation is an emerging need of any democratic or developing country. Every country provides various types of rights for its citizens and also provides remedies if any right of citizens is infringed. It is based upon the famous Latin maxim 'ubi jus ibi remedium' where right there is cure or remedy. In the present scenario the

${ }^{1}$ Tata Cellular v. Union of India (1994) 6 SCC 651. 
Himalayan J. Soc. Sci. \& Humanities ISSN: 0975-9891

Vol. 16, (2021) 55-64

DOI: https://doi.org/10.51220/hjssh.v16i1.5

traditional concept of state 'police state' has been converted into the 'welfare state' and 'democratic state'. After the implementation of the welfare state concept, the functions of government have been increasing day by day due to various complicated situations and socioeconomic disputes continuously increasing. Due to which many judicial works and power of decision making are delegated over the executive or government department, e.g., service matters of government officials, taxation matters, issues relating to the customs or foreign exchange matters, industrial and labor disputes, election matters, control over production, disputes of the company matter, etc.

It is a settled and experienced rule of the world that absolute and uncontrolled powers are always the causes of injustice and arbitrariness. So, it is important for any democratic and welfare country that makes limitations over every organ of government. In the words of Justice Quadri"The essential difference between a government of despots and a government of democratically elected persons is that in the former case, there are no limitations on the powers or their exercise whereas in the latter case, the powers are defined and their exercise is regulated by law."

The power of judicial review is a limitation or boundary or method or a process which protects our legal framework and confirms that no authority is superior to the Constitution. The Concept of the democratic country is based on the protection of citizen rights, which is possible through the fair and equal treatment in every matter of the country. India is a democratic country and the Constitution of India is the supreme law of the country, which ensures the protection in the Constitution of rights of its citizens. The review power of the judiciary is provided under the Articles 32, 226 and 136 of the Constitution of India and this power of judicial review is vested upon the Supreme Court and High Courts.

\section{Power of Judicial Review in India:}

"Judicial review is thus the touchstone and essence of the rule of law." (R.K. Jain v. UOI). ${ }^{2}$

Following subject meters are covered under judicial review-

1. Legislative actions.

2. Judicial decisions or actions.

3. Administrative actions or quasi-judicial bodies.

${ }^{2}$ (1993) 4 SCC 119.

CSHARAD 
Himalayan J. Soc. Sci. \& Humanities ISSN: 0975-9891

Vol. 16, (2021) 55-64

DOI: https://doi.org/10.51220/hjssh.v16i1.5

The judiciary checks the constitutional validity of the working or functions of legislature, executive and judiciary through the power of judicial review. If the organs failed in the test of validity, the act is declared unconstitutional through the judicial review. The Judicial review is an important power of our judiciary, it secures constitutional and legal norms of the country. There is discussion on the third aspect, judicial review of administrative actions or quasi-judicial bodies. Tribunals are covered under the third aspect and the working of Tribunals also questioned or challenged in front of the judiciary.

\section{The Grounds of Judicial review over the working of Tribunal-}

The power of Judicial review is different from the other powers of appeal, reference and revision. The Power of judicial review is not available when any alternative right is available in the relevant statute and the decision of the tribunal is final. If there are no alternative rights available then the power of judicial review can be applied. Secondly, when any authority performs ultravires actions then the action has been controlled by the judiciary. Judicial review shall be performed by the judiciary in following situations-

1. If the Decision of the tribunal is taken without jurisdiction.

2. Tribunal is failed to use the given jurisdiction.

3. Abuse of jurisdiction.

4. The Tribunal failed to follow the principle of natural justice and procedural rule of the statute and common law.

5. Justice is not shown in the decision of the tribunal.

6. Related statute is unconstitutional.

\section{Tribunals are substitute/supplemental of High Courts -}

Articles 226 and 227 of the Constitution empower the High Courts for appeal, judicial review and supervision of all the quasi-judicial bodies under provided jurisdictions. The High Court has jurisdiction in the state and there are many statutes which make the provisions of appellate tribunals and some statutes provide that the decisions of tribunals will be final. In that situation the Supreme Court has the jurisdiction of appeal of such decision of tribunals under Article 136. If we are saying that tribunals are the substitutes of the High Court, then many questions will be 
Himalayan J. Soc. Sci. \& Humanities ISSN: 0975-9891

Vol. 16, (2021) 55-64

DOI: https://doi.org/10.51220/hjssh.v16i1.5

raised - Whether Tribunals have empowered to issue any writ? Whether tribunals have power of Interpretation of law or statutes? Whether tribunals have power of judicial review?

The issue was challenged in the judgment of S.P. Sampath Kumar v. Union of India ${ }^{3}$ is a case in which the Administrative Tribunal act, 1985 (Sec. 4,5,6 and 28) is challenged. The main challenging point was that, the exclusion of the jurisdiction of the High Court under Article 226 and 227 in service matters is unconstitutional and void. Ranganatha Mishra J. observed that -

"We have already seen that judicial review by this court is left wholly unaffected and thus there is a forum where matters of importance and grave injustice can be brought for determination or rectification. Thus, exclusion of the jurisdiction of the High Court does not totally bar judicial review... It is possible to set up an alternative institution in place of the High Court for providing judicial review.... the tribunal has been contemplated as a substitute and not as supplemental to the High Court in the scheme of administration of justice.... what, however, has to be kept in view is that the Tribunal should be a real substitute for the high court not only in form and de jure but in content and de facto ....under section 14 and 15 of the Act all the powers of the court in regard to matters specified therein vest in the Tribunal-either center or state. Thus, the tribunal is the substitute of the High Court and is entitled to exercise the powers thereof." 4

The Supreme Court held that judicial review is part of our basic-structure doctrine. The court decided that if the statute provides an effective substitute for the High Court, then the judicial review power of the High Court can be excluded, but the power of the Supreme Court under Article 136 does not exclude in any circumstance. ${ }^{5}$ Article 136 is the special power of appeal of the Supreme Court, it is a discretionary power of Supreme Court. ${ }^{6}$ After the judgment of S.P. Sampath Kumar, many questions arise that, can exclusion of the power of high court be right?

${ }^{3}$ S. P. Sampath Kumar v. Union of India, 1987 AIR 386.

${ }^{4}$ Supra.

${ }^{5}$ Supra.

${ }^{6}$ INDIA CONST. art.136- Special leave to appeal by the Supreme Court

(1) Notwithstanding anything in this Chapter, the Supreme Court may, in its discretion, grant special leave to appeal from any judgment, decree, determination, sentence or order in any cause or matter passed or made by any court or tribunal in the territory of India

(2) Nothing in clause (1) shall apply to any judgment, determination, sentence or order passed or made by any court or tribunal constituted by or under any law relating to the Armed Forces.

CSHARAD $58 \quad$ http:// hjssh.sharadpauri.org 
Himalayan J. Soc. Sci. \& Humanities ISSN: 0975-9891

Vol. 16, (2021) 55-64

DOI: https://doi.org/10.51220/hjssh.v16i1.5

and, Can Article 136 have been sufficient for judicial review? In the year 1989-90 the Arrears Committee was established for discussion on this problem, in the view of the Committee the position of Tribunals is not satisfactory and encouraging in our country and there is a need of a fresh look in this system, review and serious consideration before the experiment in the fields "especially if the constitutional jurisdiction of the High Court is to be simultaneously ousted."7

In the judgment of G.B. Chopra v. U.O.I. ${ }^{8}$ the Supreme Court observed that- "The Administrative Tribunal being a substitute of the High Court had the necessary jurisdiction, power and authority to adjudicate upon all disputes relating to service matters including the power to deal with all questions pertaining to the constitutional validity or otherwise of such laws as offending Articles 14 and 16(1) of the Constitution."

After the judgements of apex court, the actual position of the High Court does not cleared and further Supreme Court rightly said that if we deemed that tribunals are the substitute of High Court than the Members of Tribunals can be claim equal treatment with the judges of High Courts in the subject of Pay-Scale and superannuation of age. ${ }^{9}$ If any tribunal became the effective alternative of the High Court, the member of Tribunals should be having legal expertise and judicial experience and a proper legal training must be required. ${ }^{10}$ Ramaswamy, J., said that "Such tribunals being creature of statutes can in no case claim the status of the High Court or parity or as substitutes. "11 In the case of State of Orissa v. Bhagavan Sarangi 12 the court held that "A tribunal established under the Act is nonetheless a tribunal and it cannot side-track a decision of the High Court concerned." In the judgment of L. Chandra Kumar v. U.O.I. ${ }^{13}$ further the issue questioned on the Supreme Court, the court held that:

"Section 28 of the Act and the 'exclusion of jurisdiction' clauses in all other legislations enacted under the aegis of Articles $323 \mathrm{~A}$ and $323 \mathrm{~B}$ would, to the same extent, be unconstitutional. The jurisdiction conferred upon the High Courts under Articles 226/227 and upon the Supreme Court under Article 32 of the Constitution is part of the inviolable basic structure of our Constitution.

\footnotetext{
${ }^{7}$ Report of Arrears committee, (1989-90), vol, II.

8 (1987) I SCC 422

9 M.B. Majumdar v. Union of India1990 SCR (3) 946.

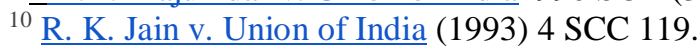

${ }^{11}$ Supra.

12 (1995) 1 SCC 399.

${ }^{13}$ AIR 1997 SC 1125.
}

CSHARAD 
Himalayan J. Soc. Sci. \& Humanities ISSN: 0975-9891

Vol. 16, (2021) 55-64

DOI: https://doi.org/10.51220/hjssh.v16i1.5

While this jurisdiction cannot be ousted, other courts and Tribunals may perform a supplemental role in discharging the powers conferred by Articles 226/227 and 32 of the Constitution. The Tribunals created under Article 323A and Article 323B of the Constitution are possessed of the competence to test the constitutional validity of statutory provisions and rules. All decisions of these Tribunals will, however, be subject to scrutiny before a Division Bench of the High Court within whose jurisdiction the concerned Tribunal falls." 14

According to a report of the Law commission of India, the tribunals are not a substitute of the High Courts, tribunals are different from the High Court ${ }^{15}$. The apex court observed in the judgment of U.O.I. v. R. Gandhi ${ }^{16}$ that parliament is empowered under the Union List of the Seventh Schedule of the Constitution to create a substitute for High Courts.

By nature, tribunals are statutory bodies because tribunals are constituted through the enactments of legislature and tribunals get the powers under the statute. The Supreme Court and High Courts are the constitutional bodies, which are established under the provisions of the Constitution.

A question raised in the respect of the Appellate Tribunal that what will be the jurisdiction of the High Court? The Law Commission of India gives the opinion in this matter, the view of commission is that-

- If the related statute does not make the provision for appellate body, then the appeal of the Tribunal may lie on the High Court.

- The order of any Tribunal and Appellate Tribunal wherever it exists, or attains finality it will be challenged on the Division Bench of the High Court, which have territorial jurisdiction over the Tribunals and its appellate tribunals.

- Further, the Commission suggested that- "For the effective working of this idea, it will be necessary that the Appellate Tribunals established must act judiciously and that such Appellate Tribunals should be constituted at par with the High Courts and the members appointed in these Tribunals should possess the qualifications equivalent to that of the

${ }^{14}$ L. Chandra Kumar v. Union of India AIR 1997 SC 1125.

${ }^{15}$ LAW COMMISSION OF INDIA Report No.272 Assessment of Statutory Frameworks of Tribunals in India Oct., 2017.

${ }^{16}$ (2010) 11 SCC 1.

CSHARAD 
Himalayan J. Soc. Sci. \& Humanities ISSN: 0975-9891

Vol. 16, (2021) 55-64

DOI: https://doi.org/10.51220/hjssh.v16i1.5

High Court Judges. If appeals against the decision of Appellate Tribunals are brought before the concerned High Courts in a routine manner, then the entire purpose of establishing Tribunals will get frustrated. Therefore, the Commission is of the view that the aggrieved party against the decision of such Appellate Tribunal should be able to approach the Supreme Court on the grounds of Public or National importance and not before any other authority." 17

At present the hierarchical system of tribunals is arising and the purpose of this hierarchical system is to provide finality in matters, but the finality clause is relevant only in matters of appeal. The judicial review is broader than the appeal, reference and revision. The supervisory jurisdiction and controlling power of the High Court is the constitutional power which is vested under the Articles 226 and 227 of the Constitution.

\section{The Judicial Review and the Independence of the Tribunal:}

Independence is an important characteristic of the justice delivery system. It is possible by an independent body to deliver fair and quality justice for all. Judicial review is not an exception of independence of tribunals, it is only a controlling and superintending power of the judiciary and it is also required because it has been the age-old experience of the world that giving absolute and uncontrolled powers to a single authority has always bad results which has always given rise to autocracy and injustice. A controlling authority is always needed in society, for maintaining social order and justice. It is important for complete and fair justice to make some limitations. "The underlying object of judicial review is to ensure that the authority does not abuse its power and the individual receives just and fair treatment and not to ensure that the authority reaches a conclusion which is correct in the eye of law." ${ }^{18} \mathrm{All}$ the organs of governments come under the purview of the Constitution, and no one is permissible that breach the provisions of the supreme law. Judicial review is not against Tribunalisation even most of the time the judiciary ensures the independence of tribunals. For example, in the judgment of Rojer Mathew v. South Indian

\footnotetext{
${ }^{17}$ LAW COMMISSION OF INDIA Report No.272 Assessment of Statutory Frameworks of Tribunals in India Oct., 2017.

${ }^{18}$ Chief Constable v. Evans, (1982) 3 All ER 141: (1982) 1 WLR 1155; Sterling Computers Ltd. v. M \& N Publications, (1993) 1 SCC 445, 458: AIR 1996 SC 51; Mahesh Chandra v. U.P. Financial Corpn., (1993) 2 SCC 279; G.B. Mahajan v. Jalgaon Municipal Council, (1991) 3 SCC 91: AIR 1991 SC 1153; LIC of India v. C.E.R.C., (1995) 5 SCC 482: AIR 1995 SC 1811.
}

CSHARAD 
Himalayan J. Soc. Sci. \& Humanities ISSN: 0975-9891

Vol. 16, (2021) 55-64

DOI: https://doi.org/10.51220/hjssh.v16i1.5

Bank Limited \& ors. ${ }^{19}$ the court decided that, the provisions which are related to the removal of the judges of tribunals by the executive, the provisions are unconstitutional and there should be a common age of retirement for judges because the short term of tenures is against the independence of judiciary. ${ }^{20}$ The Court maintained the independence of the Tribunals and struck down the provisions of the Tribunals reform Act, 2021 related to the tenure of members of Tribunals, the court held that members will have the term of 5 years or 67 years of age. The court makes a suggestion for National Tribunal Commission, which will be supervise the appointments and the functioning the Tribunals. ${ }^{21}$

\section{Position of exclusionary provisions of the Judicial review:}

Sometime exclusion of judicial review may be made under a statute inserting the provisions that the administrative action final. For e.g., The Foreigners Act 1946 allows that administrative actions are taken within the act and "shall not be called in question in any legal proceeding before any Court of law"22. Similarly, the Administration of The Evacuee Property Act, 1950 stipulates that the orders which are given under the act, shall be final and not challenged in any Court $^{23}$. Exclusion of Judicial review is only a myth because the constitutional provisions in Article 32,136, 226 and 227 secures this power. If any provisions of the statute provides that decision of tribunals is final and conclusive, it has no mean that such decision cannot be reviewed by the judiciary, if tribunals exceed the given jurisdiction, such decisions can be challenged in front of judiciary and judiciary will be reviewed of such decision and checks the validity and constitutionality of such decision. "If tribunals were to be at liberty to exceed their jurisdiction without any check by the courts, the rule of law would be at an end." 24 The original constitution of India does not unaware by the word tribunal, because the tribunal word is already included under the Article 136 and the Article 227, both Articles deal the power of the Supreme Court and the High Courts. Article 32, 136, 226 and 227 empowered the judiciary to supervise all

\footnotetext{
${ }^{19}(2019) 1$ SC C 1.
}

${ }^{20}$ (2020) 6 SCC 1.

${ }^{21}$ Madras Bar Association v. Union of India, 2020 SCC OnLine SC 962.; Madras Bar Association v. Union of India,

${ }^{22}$ Sec. 2

${ }^{23}$ Sec. 28

${ }^{24}$ R. v. Medical Appeal Tribunal, (1957) 1 QB 574 (586).

CSHARAD 
Himalayan J. Soc. Sci. \& Humanities ISSN: 0975-9891

Vol. 16, (2021) 55-64

DOI: https://doi.org/10.51220/hjssh.v16i1.5

subordinate courts, offices, tribunals and decision-making bodies, and also checks the constitutional validity and legality of actions and decisions of the all-subordinate decision-making bodies. Through this power, the judiciary is empowered to check the validity of the statute under which the tribunal is established. The judicial review power is the power which ensures the true meaning of justice and the social order. The Supreme court described the importance of judicial review in the following words-

"Judicial review is a vital principle of our Constitution and it cannot be abrogated without affecting the basic structure of the Constitution. If by a Constitutional amendment, the power of judicial review is taken away and it is provided that the validity of any law made by the Legislature shall not be liable to be called in question on any ground, even if it is outside the legislative competence of the legislature or is violative of any fundamental rights, it would be nothing short of subversion of the Constitution, for it would make a mockery of the distribution of legislative powers between the Union and the States and render the fundamental rights meaningless and futile. ${ }^{25}$

\section{Conclusion:}

Judicial review is the power under which the supremacy of law is provided. Judicial review is the most popular and important method, which regulates and secures the supreme document or law which is famously known as the Constitution of the country. It is not only the power of the judiciary but also the responsibility of the judiciary to secure the constitutional and legal norms of the country. Under the scheme of the Indian Constitution, the judicial review power is entertained through the Supreme Court and the High Court, which is interpreter and guardian of the Constitution. Tribunalisation is the need of modern welfare society and it is a supplemental part of the judiciary.

Independence is a basic feature of any justice delivery body, Through the various landmark judgements the apex court highlighted on the independence of tribunals.

Absolute independence is a danger for society. So, it is important to make some limitations and judicial review is the medium which regulates and makes the limitation over administrative

\footnotetext{
${ }^{25}$ Minerva Mills Ltd. v. Union of India, AIR 1980 SC 1789; See also Kuldip Nayar v. Union of India AIR 2006 SC 3127; Waman Rao v. Union of India, (1981) 2 SCC 362.

CSHARAD 
Himalayan J. Soc. Sci. \& Humanities ISSN: 0975-9891

Vol. 16, (2021) 55-64

DOI: https://doi.org/10.51220/hjssh.v16i1.5

adjudications. When the administrative tribunals do not work according to the constitutional norms or given power of the statute or principle of natural justice, then the judiciary reviews and checks the constitutionality of such actions or decisions. In India, the constitution is the supreme law and no one is permitted to infringed the supreme law, and the check and balance theory between the organs of government is vested in the scheme of the Constitution.

References: All 25 references are placed as foot notes. 